Copyright (c) 2021, Emerald Publishing Limited

This AAM is provided for your own personal use only. It may not be used for resale, reprinting, systematic distribution, emailing, or for any other commercial purpose without the permission of the publisher. 


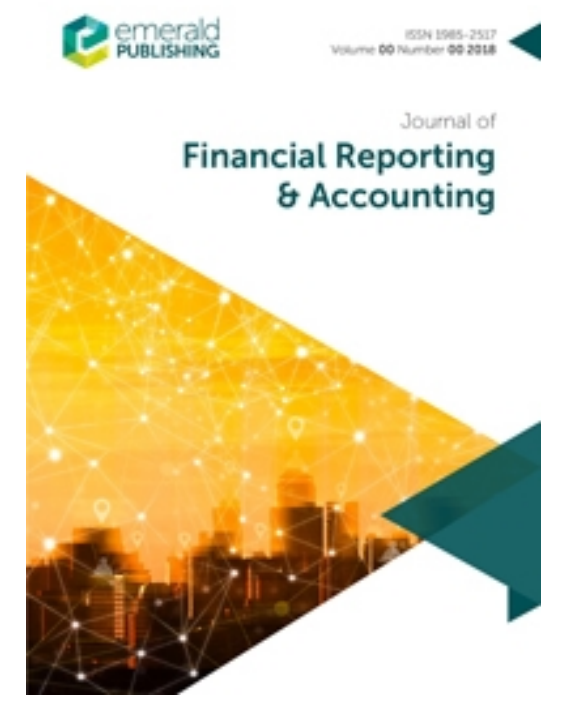

\section{An Empirical Study on company's perception of Integrated Reporting in India}

\begin{tabular}{|r|l|}
\hline Journal: & Journal of Financial Reporting and Accounting \\
\hline Manuscript ID & JFRA-03-2020-0081.R5 \\
\hline Manuscript Type: & Research Paper \\
\hline Keywords: & $\begin{array}{l}\text { Perception, Integrated Accounting, BRR Reports, Challenges, Non- } \\
\text { Financial Disclosures, CSR report }\end{array}$ \\
\hline \multicolumn{2}{|l}{} \\
\hline
\end{tabular}

\section{SCHOLARONE ${ }^{\text {m }}$ \\ Manuscripts}




\section{Article title - An Empirical Study on company's perception of Integrated Reporting in India}

Purpose - International Integrated Reporting Council (IIRC) is in its tenth year of establishment and the IR (Integrated Reporting) framework released in 2013 was under revision in the year, 2020. Despite some significant developments in the past ten years, we know very little about the perception of preparers towards integrated reporting. This paper is an attempt to study the perception of the preparers and to understand the current status of adoption of integrated reporting in India

Methodology/ Design/ Approach - Top 500 companies from ET 500 list has been analysed. Banks and financial institutions (total 69) have been excluded for the study. Out of 431 companies, the status of integrated reporting has been checked by questionnaire-based survey. Principle component analysis, a dimensionality reduction technique was performed on the responses to understand the important components impacting perception of companies. Also, a case study methodology has been adopted to compare and analyse the integrated reporting trends in manufacturing and industrial sector.

Findings - The result shows that the majority companies have positive opinion about integrated reporting, and the three major components impacting their perception are - concise reporting, effective and transparent reporting and lastly better decision making.

Practical Implications - The result of this study will be useful for the policy makers, regulators, companies who have or will adopt integrated reporting. Paper gives a relevant view to academician for assessing the effectiveness and perception of integrated reporting.

Originality/ Value - Very few studies can be found in India which focuses on analysing the perception of preparers towards the integrated reporting. Specially after the circular of SEBI in 2017, it becomes even more important to analyse the insight and awareness of the companies who have adopted integrated reporting. Our paper is a timely and relevant contribution to the literature by providing insight over opinion of preparers in India

Keywords. Perception; Integrated Accounting; BRR Reports; Challenges; CSR Report; NonFinancial Disclosures.

JEL Classification - M4, M41, M480 


\section{Introduction}

After the financial crisis, many companies have started including the sections on corporate governance, sustainability, corporate strategies, environment and social concerns of the company and actions taken by the company which shows company's concern towards community wellbeing. This has led to long and complex technical details to be presented which requires a high level of expertise to understand. Integrated reporting is a combination of a company's financial report, corporate social responsibility report and sustainability report into a single document (Adams, 2015; Eccles and Krzus, 2010) .In February 2017, SEBI's ${ }^{1}$ has encouraged Top 500 listed companies of India to adopt integrated reporting framework for corporate reporting (SEBI, 2017). It has given one-year time for adoption of integrated reporting and therefore it would be interesting to know about the current status of integrated reporting adoption and the perception of company's leaders towards integrated reporting in India.

In today's economy, companies are facing global competition, technological innovation and increased regulation imposed on them in response of Governance and Financial Crisis. Over the past two decades standalone social and environmental disclosures have increased adding more and more pressure on companies to give non-financial disclosure. Integrated reporting is a logical reply in reporting financial and non-financial disclosures. The Integrated Reporting gives a complete picture to the users about the financial and non-financial aspect of the company. Integrated Reporting is based on integrated thoughtfulness involving all types of capital, their interface and impact on short, medium- and long-term prospects of the company. Integrated reporting provides information about value creation process and also satisfies the need of transparency in the annual report (Krzus, 2011; Eccles and Serafeim, 2017).

Integrated reporting proposes value creation by giving responsible products and services to stakeholders at right time, price and place (Understanding Value Creation, June 2020). The cornerstone of the "integrated thinking" was the integrated approach of "three pillar theory" (three "P"s: People, Planet and Profit) (Elkington, 1997). This theory has significantly contributed to the initiative of sustainability and "green" economy (Elkington, 1998).

\footnotetext{
${ }^{1}$ SEBI is Securities and Exchange Board of India, It is a regulator which was established under SEBI Act 1992 and given power on 30 January 1992. https://www.sebi.gov.in/
} 
In India, corporate reporting requires some non-financial mandatory disclosures to be included other than the financial disclosures. Many regulatory bodies like Companies Act 1956, Corporate Social Responsibility Legislation, Security Exchange Board of India (SEBI), Income Tax Act 1961, Security Contract Act 1956, SEBI Listing Requirement, Business Responsibility Report (BRR) and Capital Issue Act 1947 govern non-financial disclosures. The reporting in India is combination of mandatory and voluntary disclosures. Voluntary disclosures are increasing day by day but it's still not uniform. This has led to increase in number of pages of annual report and the relevant information is generally lost in between these pages. Integrated Reporting in many ways is a solution to this. This study is an attempt to understand the status of integrated reporting in India post the SEBI 2017 circular and identify the prominent factors that govern the perception of company towards integrated reporting. Through case study analysis this study also attempts to assess the quality of the integrated report of the industry which has huge impact on society and environment.

\section{Study Motivation}

The first publication related to integrated reporting came out in June 2005 by co-founder of GRI, Allen White. In his work he concluded that integrated reporting is the future of corporate reporting. The literature review reveals that most of the studies in the field of integrated reporting concentrates on the current status of social responsibility ( Morros, 2016; Kurniawan and Wahyuni, 2018) or deals with the theoretical and empirical relevance of the topic (Burcă, 2018; de Villiers et al., 2014). Many researchers have worked on comparative literature review of traditional and integrated reporting or Sustainability reporting (Jensen and Berg, 2012; Bratu, 2017; Nurkumalasari et al., 2019). Also, we find few studies where adoption of integrated reporting has been linked with size of firm, profitability, type of industry, and ownership structure (Jensen and Berg, 2012; Frias et al., 2014; Sierra et al.,2015; Ghani et al., 2018). It has always been emphasised that there is a need to study the adoption rate of integrated reporting in developing countries (Lipunga, 2015).India is the fastest growing economy in the world and adoption of integrated reporting in India will give a huge boost to IIRC. This current study sought perceptions and experiences of Indian early adopters after the release of the $<\mathrm{IR}>$ framework in December 2013. Dumay et al. (2016) identified articles on integrated reporting that analyze specific organizations from a national perspective under the UK (Beattie and Smith, 2013) and Australian institutional settings (Stubbs and Higgins, 2014). Additionally, they highlight that majority of the work focuses on specific organisations leading to a disconnection between academic IR research and IR 
practice, which this study aims to address. This research area is increasingly relevant given growing concerns over climate change, population growth and inequity, potential resource scarcity, the global financial crises, corporate and bank failures and social and environmental disasters among other high-profile incidents (Druckman and Fries, 2010; IIRC, 2011). By seeking company's perception and experiences of the integrated reporting process, this study responds to the arguments of several prominent academics that research in the pursuit of improved environmental, social and economic performance requires closer engagement with practice (Adams \& Larrinaga-González, 2007; Gray, 2002)

From the India prospective very less studies deal with integrated reporting and the perception of the companies who have implement integrated reporting. There is a need to understand the perception of users of integrated reporting. The audit requirements of the integrated reporting will be very different as it deals with various kind of capital and value creation model. It is evident that "Value Creation" is a subjective term and every company will have its own interpretation, this is a challenging aspect for assurance provider. After a decade of $<\mathrm{IR}>$ framework, when IIRC is revising its framework in year 2020. Finding of the study will help policy makers and regulators in framing future reporting framework. This study will be helpful in identifying the opportunity and challenges faced by the adopters. This will also contribute to the gap of studies done in Indian prospect and hence act as a contribution to the existing literature.

\section{Theoretical Background}

In the past two decade, because of numerous non- financial disclosures being added to the traditional financial disclosures the complexities in reporting has increased. It was in 2004 that $\mathrm{A}_{4} \mathrm{~S}^{2}$ (Prince's Accounting for Sustainability Project) was formed with a vision to give clear directions for better reporting. They developed a framework for reporting in 2007 and a set of guidelines was given in 2009. A4S was very successful and they along with Global Reporting Initiatives ${ }^{3}$ (GRI) and International Federation of Accountants ${ }^{4}$ (IFAC) called for

\footnotetext{
${ }^{2} \mathrm{~A} 4 \mathrm{~S}$ was established by Prince of Wales in 2004 for supporting sustainable business $\&$ accounting https://www.accountingforsustainability.org/en/index.html

${ }^{3} \mathrm{GRI}$ is an independent standard organisation formed in 1997 to support transparent disclosures https://www.globalreporting.org/

${ }^{4}$ IFAC is a global organization for the accountancy profession https://www.ifac.org/
} 
establishment of IIRC ${ }^{5}$ (International Integrated Reporting Council) which was established in 2010. In November 2011, IIRC came up with numerous changes in the reporting system and it came out with its first version of Framework in December 2013.

The first integrated report was published by Novozymes in 2002. After Novozymes, Natura Cosmetics in 2003, Novo Nordisk in 2004 and many other companies like Aviva, HSBC, BT, Philips also followed the footsteps of Novozymes (Eccles et al., 2019).All these early adopters of integrated reporting didn't had generally accepted standards or framework to guide them and therefore each report was unique and different (Havlová, 2015). Stubbs \& Higgins (2014) conducted a similar study in Australia on early adopters of integrated reporting. They suggest that the organisations should support sustainability reporting. Therefore, there was a strong need for a framework which was fulfilled by $<$ IR $>$ framework. In addition to this framework a 37-page document which addressed- Capital, Guiding principle and Content element was also released.

Integrated reporting picked up after the release of framework by IIRC and reports show that in 2018, top two countries reporting integrated reporting are South Africa and Japan with a combined of $43 \%$ of reports identified as integrated report (IIRC,2018). Asian counties are also doing very well in this field and are adopting at very high phase. Countries like Srilanka, India, Malaysia, Thailand and Philippines are key contributors. To its contrast, developed countries like Canada, Germany and USA are lagging. Research also focus that industries like Insurance, Banking, Retail, and wholesale with more intangible and intellectual capital are more inclined towards adopting integrated reporting.

In India, after the release of $<\mathrm{IR}>$ Framework in 2013, Security Exchange Board of India (SEBI) chairman Mr. U.K. Sinha invited Confederation of Indian Industry (CII) to prepare a roadmap on Integrated Reporting in India (Mishra, 2020). SEBI also formed Kotak Committee to help improve Corporate Governance in the listed companies. Not many companies adopted Integrated Reporting in India after 2013, and then on $6^{\text {th }}$ Feb 2017, SEBI came up with a circular stating that Top 500 listed companies of India should voluntarily adopt integrated reporting from the next financial Year. Kirloskar Brothers Ltd was first to adopt integrated in 2013-2014 followed by Tata Steel in 2014-15 (Mishra, 2020a).

\footnotetext{
${ }^{5}$ IIRC is a global coalition which is established to promote communication about value creation and bring evolution of corporate reporting. https://integratedreporting.org/
} 


\section{Literature Review}

de Villiers et al.(2014) is one of the most prominent researchers who has highlighted various research opportunities related to integrated reporting. He has done a revelatory review of the integrated reporting and sustainability reporting. He came up with 30 questions and also raised valid points which focuses on the issues faced in integrated reporting. Haller and van Staden (2014) connect integrated reporting with integrated thinking. Many researchers (Brown and Dillard, 2014) have highlighted that integrated reporting is primarily used for providing information about financial capital and how organization creates value overtime. Also, few researchers have focused on management control system of integrated reporting (Beattie and Smith, 2013; Gasperini, 2014; Lodhia, 2015; Dumay and Dai, 2017).

Many researchers have focused towards the issues faced by companies after adoption of integrated reporting (Jensen and Berg, 2012; Reuter and Messner, 2015). Whereas other articles propose new methods to improve integrated reporting (Mertins et al., 2012; Cohen and Karatzimas, 2015). Cheng et al. (2014), discussed about the issues in the $<\mathrm{IR}>$ framework and suggest ways to explore solutions. Few researchers have discussed about the quality of disclosures in the integrated report (Cortesi and Vena, 2019; Mishra, 2020b). John Dumay (Dumay et al., 2010; Dumay, 2016; Dumay et al., 2016; Dumay and Dai, 2017; La Torre et al., 2020) has also done lot of work around integrated reporting and in his initial work in 2010 he has explored the GRI guidelines and talked about intellectual capital. In his study he has also highlighted few issues which the IIRC face and suggest that IIRC should come up with solutions (Dumay et al., 2017; La Torre et al., 2020). Abeysekera, (2013) proposed an outline of the integrated reporting with a template for the organisations.

van Bommel, (2014) found that sustainability reporting appealed to the broader range of stakeholder and was more flexible whereas de Villiers et al. (2014) criticized sustainability reporting and argued that integrated report will bring a real change in the organization's system. Few studies conducted in South Africa after the mandatory inclusion of integrated reporting in 2011, shows that there is a favourable impact of integrated reporting on reducing the risk (Conway, 2019). It was also found that most of the articles are written by academicians and very less articles are written by practitioners (Mertins et al., 2012; Soyka, 2013; Churet and Eccles, 2014; Flower, 2014; Gasperini, 2014; Robertson and Samy, 2015; Federica et al., 2016; Eccles et al., 2019) Therefore, Lodhia (2015) has specially brought attention towards the fact that integrated reporting is a new concept and there is a need for 
more research in this area. We can always see a gap between academicians, practitioners and policy makers. Therefore, Evan et al. (2011) has emphasised on being more commutative and better coordination between policy makers, academicians and practitioners. Melloni et al. (2017) worked on investor's reaction to integrated reporting and exhibited that integrated reporting gives a positive signal towards investors.

As the integrated reporting framework has completed its ten years, now the researchers are focusing on the development of integrated reporting. Few studies have shown that IIRC embraces their capitalist ideology and transpose it to integrated reporting (Rowbottom and Locke, 2016; Humphrey et al., 2017). La Torre et al. (2020) has examined various reports and framework of IIRC and examined the rhetorical process with the view to understand the ideological work done by IIRC over a decade.

While going through various articles and papers it was found that there is very less study on integrated reporting in India. Athma et al. (2013) in their work has concluded that integrated reporting should be promoted among the companies to increase its adoption. Ghosh (2019) concluded that governance and performance are two most relevant factors in integrated reporting in India.

\section{Research Methodology}

The main objective of the paper is to gain an insight into perception of integrated reporting in India. To address the objective Top 500 companies from ET 500 list published by Economics Times- India (2018-19) was taken. The reason for choosing top 500 listed companies was because of the SEBI's circular regarding integrated reporting which addressed only top 500 listed companies who are reporting BRR (Business Responsibility Report). Companies having market capitalization of more than 1 billion rupees are ranked based on total income in financial year 2018 and the annual report released before Sept 30, 2018 has been considered. And the Companies trading on less than $75 \%$ of the total traded days on the BSE during the period of April 2018 to October 2018 has been excluded. For this study, banking and financing companies has been excluded from the data base because of difference in their reporting style. Total there are 69 Banking ad financing companies, after excluding them the number of companies considered for the study is 431 .

Annual Report of all 431 companies were analysed to select the companies following integrated reporting. The study was divided into two parts, firstly the reports were analysed to understand their reporting style and secondly, a questionnaire was designed based on the 
IIRC's framework and the literature review relating to the challenges, opportunities, advantages and disadvantages of adopting integrated reporting and was sent to these selected companies.

By analysing annual report, it was found that out of 431 companies, 33 companies followed integrated reporting in the financial year 2018-19. A structured self-administrated questionnaire was sent to selected companies. The companies which have not adopted integrated reporting were not included in the study. The reason behind this was huge number of companies who have not adopted integrated reporting. Because the structure of the study deals with primary data collection it would be very difficult to undertake the survey. The survey assessed the perception of targeted personnel towards advantage, disadvantages, opportunities and challenges.

The questionnaire was divided in six parts, Part A was general demographic questions, Part B questions were based on perception towards advantages of integrated reporting, Part $\mathrm{C}$ was based on implication of integrated reporting, Part D was future opportunities of integrated reporting, Part E was question for challenges faced and Part F had few questions targeting the understanding of integrated reporting. Part B, C, D and E were 5-likert scale questions ranging from 1 (strongly agree) to 5 (strongly disagree). This was used to rank respondent's perception towards the statements in the survey. Since the concept of integrated reporting are relatively new in India and few companies have adopted it, therefore more wide-ranging questions were raised as compared to in-depth questions. Also, the respondents were asked about whether they understand integrated reporting, six capitals in integrated reporting, meaning of value in company's objective etc and the results were shocking. These questions were covered in section F.

In every selected company at 3-4 person were approached with the questionnaire to ensure correct input of the questions and a successful survey. Selection of these respondents was done based on their work profile and accessibility. Only those personals were selected for the survey who were working around preparation of integrated reporting. A pilot study was done with 5 respondents who were requested to evaluate the questionnaire based on the clarity or ambiguity, time required to complete the questionnaire, the of the questions, and the clarity of the instructions and questions were reframed according to their feedback. A total of 132 mails were sent to 33 companies. Incomplete questionnaires were excluded. In total 43 filled questionnaires were taken as base of the Survey based study. 
The data collected from the questionnaire was analysed by descriptive analysis, Correlation analysis to find out the level of correlation between different questions and finally principle component analysis was done on questions from section B, C, D and E. There were total 15 questions in these sections all together. Principle component analysis (PCA) is performed on these questions to understand the underlying behavioural measures which impact the perception of the company towards integrated reporting (Kinser and Kinser, 2018).

PCA is a method of dimension reduction where the variables (v) are reduced to the principle components ( $\mathrm{p}$ ) where always $\mathrm{p}<\mathrm{v}$ ('Principal component analysis and redundancy analysis', 2007). It is basically an iterative process which starts with finding first PCA dimension representing data with highest variance and then moving on to the second PCA dimension with second highest variance. It continues till the principle component represent the Comprehensible and the interpretable phenomena of the original variable.

After analysing the questionnaire, 4 companies from Manufacturing and Industrial Sector are taken. Namely: Tata Steel, Larsen \& Toubro, Vedanta Ltd and JSW Steel. The companies have been selected based on their market capitalisation. AICL Communications Ltd was the partner for all four companies in making Integrated Report. Various interview and openended discussion were conducted with Directors and CEO of AICL Ltd for understanding the issues and challenges faced by the companies in its journey from an Annual Report to Integrated Annual Report.

\section{Discussion of Results}

The questionnaire began with individual data on the respondents, reported in Table 1. Overall, it had seven questions and the result of four has been shown in Table 1.

\section{Insert Table -1}

In the study maximum respondents were male and only $3.33 \%$ respondent were female. The questionnaire was sent to the preparers of the integrated reporting of the companies and maximum respondents $(86.67 \%)$ were in the age group of $40-50$ years which obviously meant that the respondents were experienced. This led to a very adequate sample for the objective of the investigation. Majority of the respondents were finance officer (83.3\%) who were either manager or senior manager in the department. $0.3 \%$ of the respondent were compliance officers and only $0.1 \%$ was answered by CFOs of the company.

Insert Table - 2 
Table -2 shows the response rate of the survey. $32.57 \%$ was the overall response rate. A similar Survey Varenova et al. (2013) reported 17\% response rate was deemed to be acceptable for the purpose of the Study. In comparison $32.57 \%$ response rate was considered to be favourable and hence statistical evaluation was conducted.

After checking the response rate, the next step was to check the validity and reliability of the data. The purpose of this is to exhume any error in the measurement of the variables.

\section{Insert Table -3}

"Validity is the extent to which an instrument measures what it has been designed to measure, in that it will stand the test of time for subsequent research” (Field, 2013).

Any discrepancies in the questions will give undesirable results. Table 4 shows the score of Cronbach's Alpha which ranges from 0.676 to 0.837 in different sections of questionnaire (Goforth, 2015). Since all the values are greater than 0.5 validity of the data is high and further analysis can be done.

For all other parts of the questionnaire other than Part $-\mathrm{A}$, a 5 scale likert scale questions were framed and therefore the variables were all ordinal in nature. Generally, we use Pearson Correlation matrix, but it would be worth mentioning that here the ordinal variables do not have a metric scale and tend to be weakened due to the restrictions on range and therefore polychoric correlations was performed to find the correlation between the variables(HolgadoTello et al., 2010). Results are shown in Figure-1

\section{Insert Figure-1}

In figure -1 negative values are denoted by red colour and positive values are shown in blue, and the higher the absolute value of the correlation, the darker the colour. In few questions we observe high correlation. Like Q6 \& Q1 show a high correlation because they deal with the conciseness of the report which leads to better decision making. Similarly, high correlation can be seen between Q6 \& Q15 which deals with decision-making and consistency in the annual report. If components show high correlation, a component reduction method should be adopted to have better interpretation of result and therefore for fulfilling the objective of finding out important factors representing the perception of the company's principle component analysis was performed. As we know there are too many factors or variables in a study, therefore principle factor analysis is the best tool which can be used to analyse data. 
PCA is a data reduction tool and is part of the factor analysis family (Yong and Pearce, 2013). It shows the importance of variables and its overall impact on the independent variable. It is sensitive to the variance. Bartlett's test of sphericity was conducted on the data and for our study it came 0.623 which is acceptable. Watkins, (2006) suggests that component should be extracted with eigenvalue higher than 0.8 and based on scree plot.

\section{Insert figure -2}

As suggested by Cattell, (1966) a scree plot can be used to identify the number of relevant factors essential to capture the essence of study. By looking at the scree plot we can visualise the magnitude of variability associated with the components in the PCA which can be extracted for the interpretation. Inspecting the scree plot, percentage of variable explained and the eigen value, we confirmed five components are significant. The five component explains $77.22 \%$ of the variables. Out of five components selected, two were eliminated due to low factor loading. Factor loading shows the correlation coefficient of factor and the variable and also highlights the variance explained by the variable in the selected factor. Low factor loading suggests that the correlation coefficient is not satisfactory and therefore such factors can be dropped. So, the three components retained explained $57.9 \%$ of the total percentage variance. The Cronbach Alpha was performed in these three factors and the result ranged from 0.643 to 0.781 . Since the cut off is 0.6 , this indicated satisfactory level and three components were considered meaningful. The factor loading has been shown in Table- 4

\section{Insert Table-4}

Table- 4 explains the factor loading of different questions of section B, C, D and E. First factor explains $25.5 \%$ of the variance, second explains cumulative $42.3 \%$ and third with cumulative variance with $57.9 \%$. The three meaningful components extracted include questions shown in table 5 and where renamed as - "Concise" reporting, "Transparent \& effective" and "Better Decision". Table- 5 shows the summary of the factor categorisation.

\section{Insert Table -5}

Section F also had close ended questions with only two option as yes or no. The response of two questions of section $\mathrm{F}$ are shown in table 6 and 7. The responses clearly show that even the prepares feel that the finance personnel are not completely well versed with some of the principles of the framework. They also feel that the audit assurance of integrated report is complex 


\section{Insert Table -6 \\ Insert Table -7}

\section{Case Study Analysis of Selected Companies}

Second part of the study is a case-study based analysis of selected companies in manufacturing and industry sector (de Vries, 2020). For this study four companies are selected. The choice of company is based on their market capitalisation. Brief about the four companies are discussed below

Tata Steel: The Tata Steel group is world's second most geographically diversified steel company which operates in 26 countries \& has commercial presence in 50 countries. It was established in the year 1907 in Jamshedpur, India. The company's founder Shri J.N.Tata is known for being hallmark in corporate ethics. Following his philosophy, the company was one of the initiators in adopting Integrated Reporting in India in Financial Year - 2015-16. The company was conferred with "Asia'a Best Integrated Report Award" by Asia Sustainability Reporting Award 2017 in Singapore on $6^{\text {th }}$ Feb 2018.

The perception of leaders of Tata Steel is clear from the statement of CEO \& MD Tata Steel Mr TV Narendran "The Integrated Report helps us present our principle of Sustainability to out stakeholder"

JSW Steel 2017-18 - JSW steel is a flagship company of JSW group, formed in 1982 this is a leading steel manufacturer. It is one of the fastest growing companies in India. The company is spread in over 100 countries. Following the philosophy if "better Everyday" the company voluntarily adopted the integrated report in the FY 2017-18 and presented its first integrated report on $31^{\text {st }}$ March 2018. In 2018 company was recognized as "Industry Mover" by Dow Jones Sustainability Indices under their corporate sustainability assessment.

Vedanta Ltd - Vedanta Ltd, is a natural resource company dealing with Zinc lead silver, oil $\&$ gas, aluminum power, iron ore, steel \& copper. Company core principle of "we are growing responsibly" contributes to the nation's growth and assist in the process of modernization. Vedanta Ltd adopted integrated reporting in the FY 2016-17 even before the SEBI guidelines. 
L\&T Ltd - Larsen \& Toubro is a major engineering, construction, technology, manufacturing \& financial service company with global operation. With its philosophy of "Networked for Higher Return on Capital" the company released its first Integrated Reporting in the FY 2017-18. A decade ago, it was the first company in Engineering and Construction space in India to report on sustainability.

\section{Key Parameters for Integrated Reports.}

In this study authors have tried to compare the four companies taken as case study on certain parameters and tried to draw conclusion as how the companies are working in their Integrated Report. In the paper authors have tried to map the best practices followed internationally with the four companies taken into account. The appropriate representation of each aspect helps the companies to adhere to the Guiding Principles and Content Elements of the Integrated Reporting (IR) Framework. The 13 key parameters are discussed as under and then the company specific information is concluded in the chart below: -

Type of Integrated Report - In India there are majorly four type of Integrated Reported which shows their way of presentation and delivery format.

a. Standalone Integrated Report - In this a separate integrated report titled "Integrated Report" is made according to the $<\mathrm{IR}>$ Framework of IIRC. Larsen \& Toubro Ltd is an example of standalone integrated report.

b. As separate section of Annual Report - Only few key aspects of the Integrated Report are included in the annual report like capital definition, value creation model, governance model. For example, Wipro and Yes Bank

c. Sustainability Report made in accordance with $<\mathrm{IR}>$ framework - This report is named as sustainability or value creation report. This kind of report is an overlay of $<$ IR $>$ framework on GRI (Global Reporting Initiative) standard based reporting. For example, Dr Reddy Laboratories, Mahindra Finance and Grasim Ltd

d. An Annual report in the form of Integrated Report -This kind of report is a true Integrated Report in all senses and cover all important aspects. All sections are interlinked and all kind of disclosures are done. For example, Tata Steel, JSW steel and Vedanta Ltd 
For the four companies which we have taken into consideration, Larsen \& Toubro (L\&T) follows the standalone integrated report, but the rest three i.e Tata Steel, JSW steel and Vedanta Ltd follow fourth type of integrated Report i.e an Annual report in the form of Integrated Report.

Amongst the three who have gone for a full annual report in the form of Integrated Report, Tata Steel has also gone for digital report in the year 2017-18 which help the reader navigate better through the report making it more reader friendly. Followed by JSW steel in 2019-20.

Year of Adoption - Tata Steel was the one of the initial adopters of IR in India. It adopted in the FY 2015-16. Vedanta Ltd started making annual report according to $<$ IR $>$ framework in FY 2016-17. Jindal Steel and Larsen \& Toubro started their IR journey in FY 2017-18.

Capital Definition - Integrated thinking is based on multi- capital approach. It is very important for companies to identify the different resource and relationship of capital and their impact on other resources. Therefore, the inputs, outputs and value creation of each capital should be ascertained. We must also understand that each company must customize the specific capital according to their inputs and outputs. We should be very clear about the difference of output and outcomes. Output are quantitative whereas outcomes are qualitative. According to authors analysis, all companies have reported the six type of capital, but Jindal Steel offers the introduction of the six capital as early as in page 4 of its annual report. Capitals are well defined and interrelated. Then a separate dedicated chapter is also included where company clearly illustrated the capital's contribution to value creation and clearly specify the outcomes and outputs. They have illustrated it with self-explaining diagrams. Tata Steel has shown clear strategic focus in each capital, followed by the statement of way forward and its impact on SDGs. Vedanta Ltd has also shown the six capital, but in comparison to the other three companies the disclosure is not able to clearly distinguish between the outcome and output of each capital. L\& T has done the disclosure of six capitals in a unique way by showing it as part of "Business Model". This kind of disclosure covers each point and is also easy for reader to go through it. 
Value creation model - The value of the company is created either for the business or for its stakeholders in short, medium and long term. It is important for stakeholders to be aware of the organization's value creation process. A clear and concise portrayal of business model helps a company show its value creation process. Tata steel shows the value creation model and link it with its business model. It is presenting a complete insight into the company's purpose, vision and strategy with resources it employs to impact stakeholders. JSW steel links its outcome and output with value creation but does not link it with company's vision. Vedanta Ltd attempts to represent the value it creates and categories it as per six capitals. In L\&T this section is not emphasized much, and company lacks in connecting it with its mission

KPIs and performance analysis - Stakeholders must be informed as how companies are performing against its strategic objectives and whether the company's performance is helping it meet its purpose. In Vedanta Ltd, in its initial pages it presents a holistic overview of the core business with performance metrics. This report later outlines a comprehensive range of KPIs for investors to get better understanding of company's performance. The three years' trend of every indicator adds more to the narrative. JSW Steel apart from highlighting the year, each capital driving has been defined and a performance metrics has been attached to it. The crosslinked capital pages' outline detailed performance under each capital in the later pages. An interesting element is that the JSW steel in its "At Glance" section has highlighted how company became a leader in all performance metrics

Stakeholder engagement and materiality - Tata Steel annual report presents an overview of their business and associated activities that help in stakeholder engagement. Material issues are gathered from multiple channels and forums of engagement across the organization and from external stakeholders. In financials year 2018-19, Tata Steel updated its Environmental, Social and Governance (ESG) material issues and incorporated them in its long-term plans. Vedanta Ltd also gives priority to the material issues and comprehensively presents it in its annual report. Going a step forward Vedanta goes a step forward and connects it with sustainability targets and performance on these material issues as part of its strategic framework. L\& $\mathrm{T}$ does not present materiality through any matrix but just highlight various materiality concerns of the company. JSW steel also puts less emphasis on materiality and stakeholder engagement. 
Risk \& Opportunity - Business exist in an interconnected world and the external environment influence their capacity of value creation. It is therefore important to show case impact of environment on risk and opportunities, along with strategic responses. Vedanta Ltd identifies the pertinent macroeconomic opportunities and how the company will drive value from it. The company is exposed to multiple risk and the company's report clearly outline the necessary system that it has in place to manage those risks. Besides classifying the risk and uncertainty in four broad categories (financial, operational, sustainability and compliance) each risk is after elaborated with detailed appraisal of its impact, its direction and relevant mitigation measures. Tata Steel clearly highlights its risk as the focusing issue and addresses each issue. It gives the planned action against each risk it possesses and list down key actions for each risk factors. It divided its risk under 9 heads and focuses each risk and highlights the action taken. Such risk and opportunity matrix and focus are missing in JSW steel and L\&T. They incorporate in their annual report but a separate and a detailed emphasis is missing.

Environment and Social disclosure - A truly integrated report is the one which emphasize on financial and non- financial information equally. Environmental and social disclosures form major part of non-financial information and hence is an integral part of integrated report. Vedanta Ltd in its annual report clearly discloses this information under the heading "Sustainability \& CSR". It lists out the key matrix, program updates and programs initiated under company's sustainability framework. Clear targets were identified and against each target progress has been evaluated. In Tata steel the ESG initiatives have been discussed under "Social \& Relationship Capital" and also under mandatory CSR disclosures. Same with JSW and L\&T, the CSR disclose is part of their mandatory disclosures, but report does not provide any extensive insight on key performance indicators on social matrix.

Performance analysis and SDGs - Mapping of organization's progress towards the SDGs become extremely relevant aspect of an integrated report. With corporates playing a major role in the global sustainable development disclosure, it is increasingly important to understand the contribution that a company is making towards the fulfillment of the SDGs. The SDGs provide a framework that helps reporting entities map their stakeholder value- creation process against the 17 global goal and their respective targets. JSW steel has dedicated a page where they have linked the six capitals that drive value for JSW steel against SDGs. Every target under 
the identified SDGs has been cross referenced to prior sections with respective initiatives. Tata steel has also identified and prioritized SDGs that the company believes has more meaning and connected with each of the six capitals. The report links the business with its contribution to SDGs. Vedanta Ltd annual report has referred about SDGs but they have not linked it with their capitals and initiatives. Similarly, L\& T has also not emphasized much on SDGs. A summary analysis of all the parameters discussed above is shown in table 8

\section{Insert table -8}

\section{Case study analysis}

The second part of this study is a case study analysis, which is similar to the approach followed by $\mathrm{Du}$ Toi et al. (2017), where we have reviewed the integrated report of four companies with high environmental and social impact. The report of these companies where assessed on various parameter (as discussed in table -8) and the result shows that there has been a distinct characteristic in each report. When compared with just the previous year's report, before the year of adoption, one thing which was common in all the reports was that the length of the annual report has reduced. But it was also observed that even after adopting the $<\mathrm{IR}>$ framework the reports are not very concise. The length of the annual report still ranged from 346-445 pages. This is mainly because of numerous mandatory disclosures required in India. Also, it was found that even in the same sector (like Steel) there was uncertainty as to the amount of reporting required which made the reports non-uniform.

It was found that companies have adopted $<\mathrm{IR}>$ framework in different ways and the companies who have adopted it as standalone report form missed many distinct characteristics of $<\mathrm{IR}>$ framework. For example, in L\&T's annual report, the value creation model was not much emphasised and there was less prominence of stakeholder's engagement matrix

It was also observed that with integrated reporting becoming more older, it became finer. Year on year, the integrated reporting of companies has improved, and they have shown their value creation model with more lucidity.

The study illustrates that the integrated reporting is still in the development stage and it will take time for companies to totally adopt the model and bring it on board. But the analysis of four companies clearly pointed out that the number of disclosures on social, environmental 
and SDGs has increased after adoption of $<\mathrm{IR}>$ framework. The reports show more information related to stakeholders and will definitely guide the investors to take the decision.

\section{Conclusion, Limitation and Suggestion for Future Research}

Integrated Reporting is a new approach of reporting and is representing the new evolution of accounting (Pavlopoulos et al., 2019). Integrated reporting is representing a long line of innovation to the present level reporting in companies (Melloni et al., 2017). No matter very few companies have adopted integrated reporting in India, several reasons raise the importance of investigating the perception of adopters towards integrated reporting in India. First, India, like other emerging economies, needs international financial resources to finance high growth rates. Insufficient transparency in annual report is one of the most significant obstacles for emerging countries to access international capital. Companies require more and more forward-looking disclosure in their annual reports (Stacchezzini et al., 2016; Elgammal et al., 2018; Kılıç and Kuzey, 2018). Integrated reporting could become a widespread practice in India as a tool for improving corporate transparency to enhance foreign capital inflows.

The study provides a valuable insight on the perception of leaders, accountants, finance personnel and preparers of integrated report in India. The respondent's response supports the notion that integrated reporting is important. It also supports its advantages and are contented with the implications of Integrated Reporting. The study provides confirmatory evidences that integrated reporting has impending perspective. Therefore, it can be concluded that company leaders and finance personnel have positive perception towards Integrated Reporting.

The result of principle component analysis highlights three components which can be identified as the most important component for adoption of integrated reporting. Concise reporting, transparent \& effective reporting and better decision making are identified as the three most important factor which lead to positive perception of adopters. Previous studies have also highlighted the importance of concise and transparent reporting (Krzus, 2011; Melloni et al., 2017; Joshi et al., 2019).

But the study also recognizes the challenges identified by the preparers. The prepares feel that the integrated report may come up with the risk of inconsistency and may face lack of trust because of broad guidelines. The study also works on the areas like basic understanding of integrated reporting, understanding of six principles and different type of capital in integrated reporting. It can be seen from the result that the company's leaders are of the 
opinion that there is a lack of understanding which may led to lesser benefit. Many of the respondent claim that majority of the finance personnel don't understand the linkage of six capitals with value creation.

The issues and challenges of the companies are clearer with the case study analysis of the four companies conducted by the authors. It highlights the weak and the strong elements in integrated report of the selected companies. The study highlights that in India there are different style of adoption of integrated reporting out of which two most common types have been discussed in detail in the case study analysis. The study illustrates that after adoption of integrated reporting in these companies the number of disclosures related to ESG (Environmental, Social and Governance) has increased but the reports are not concise. This clearly shows that regulators must give clear guidelines about the reporting requirement and there is a need to create more value driven report.

The study also suffers with some limitations. The participants had different degrees of familiarity with the integrated reporting which could have influenced the quality of response. Author has tried to mitigate this problem with the pre-test of the survey instrument and the problems highlighted by the respondents were detected. Secondly the study has been conducted in India where integrated reporting is still not mandatory. SEBI has given a voluntary discretion to the companies to follow integrated reporting. Because of this fact the number of companies following integrated reporting were very less. But India has witnessed a strong rise in the number of companies following Integrated Reporting. In India most of the company enter a non- disclosure agreement with the employees and because of this most of the employees who were contacted to fill the questionnaire were not comfortable filling it and because of this the response rate was relatively low.

Despite the study's limitations, the result is relevant for future research. Also because of very less study on integrated reporting in India very less information about the Indian companies are available. Even though preparers are very important stakeholder, still the study reflects the opinion of small part of the overall stakeholders. Further study should be conducted to cover opinion and perception of other stakeholders, specially the consultants or the report designers should be considered in the future study. Also, to understand the real opinion of the stakeholders it would be better if future study concentrates on open ended question.

\section{Recommendations}


Integrated Reporting is not just reporting it is more meaningful reporting. Overall, it has been found in this study that the perception towards integrated reporting is positive in India. The respondents believe in the benefits of the Integrated Reporting. But it is observed that there is a lack of understanding of various types of capital and value creation model. Authors will recommend that the concept of integrated reporting should be included in the management accounting syllabus. A study conducted by ACMA (2014) also support this where they have concluded that it should be included in the professional and postgraduate level. With CIMA and ACCA already taking lead in this field, similar initiative is required by ICAI and ICMAI in India.

In line with few earlier studies, this study also identifies lack of assurance in integrated reporting (Sierra et al., 2015; Reimsbach et al., 2018). Steps should be taken to improve assurance level of the Integrated Reporting. Reporting companies should work on the reporting system of non-financial information and work on the development of better audit procedures of the Integrated Reporting.

Integrated Reporting is a new reporting system and it is representing a next evolution of accounting (Adams and Simnett, 2011). Although it has been adopted by very few companies in India, but it is supported by the company's leaders. The introduction of clear directives may increase the adoption on Integrated Reporting in India. Also, the major problem which companies in India is facing is lack of awareness of integrated reporting principles and value creation which calls for change in accounting education (Mishra, 2020c).

Companies are already overloaded by many reporting mandates. There is a need for clear directives from regulators which will help companies to come with a comprehensive reporting format.

\section{Implication of Study}

Our paper has a number of practical implications. This paper should allow to understand the reporting style and the challenges, opportunities, advantages and disadvantages of adopting integrated reporting from the Indian perspective which is one of the largest and fastest growing emerging economies in the world. The paper also made an attempt to map the best practices by analysing the four Indian companies that may be beneficial to other Indian companies in adopting and implementing the $<\mathrm{IR}>$. Furthermore, the paper also focused on management control system of integrated reporting and provided information about financial capital and how organization creates value overtime. Additionally, the study also enriches 
practical knowledge about adoption of integrated reporting at the local level. This will help regulators and authorities in framing their policies regarding mandatory and voluntary disclosures.

Finally, our survey confirms that there should be a clear distinction between the outcome and output in the business model of $<\mathrm{IR}>$ framework. This recommendation had been adopted by IIRC in their revised $<$ IR $>$ framework released on 19th Jan 2021.

\section{References}

Abeysekera, I. (2013), “A template for integrated reporting”, Journal of Intellectual Capital, Vol.14 No.2 pp. 227-245.

Adams, C. A. (2015), "Critical Perspectives on Accounting The International Integrated Reporting Council : A call to action”, Critical Perspectives on Accounting, Vol. 27 No.1 pp. $23-28$.

Adams, C. A. and Larrinaga-González, C. (2007), "Engaging with organisations in pursuit of improved sustainability accounting and performance", Accounting, Auditing \& Accountability Journal, Vol.20 No.3 pp. 333-355.

Adams, S. and Simnett, R. (2011), “Integrated Reporting: An Opportunity for Australia's Not-for-Profit Sector", Australian Accounting Review, Vol. 21 No.3 pp. 292-301. 
Athma, Prashanta and Rajyalaxmi, N, (2013), "Integrated Reporting: The Global Scenario", The IUP Journal of Accounting Research and Audit Practices, Vol. 12 No 3 pp. 7-18.

Beattie, V. and Smith, S. J. (2013), "Value creation and business models: Refocusing the intellectual capital debate", British Accounting Review, Vol.45 No 4 pp. 243-254.

van Bommel, K. (2014), “Towards a legitimate compromise?: An exploration of integrated reporting in the Netherlands", Accounting, Auditing and Accountability Journal, Vol.27 No.7 pp. $1157-1189$.

Bratu, A. (2017), "Empirical study regarding the integrated reporting practices in Europe", Audit Financiar, Vol 15 pp. 613-625.

Brown, J. and Dillard, J. (2014), “Integrated reporting: On the need for broadening out and opening up", Accounting, Auditing and Accountability Journal, Vol. 27 No.7 pp. 1120-1156.

Burcă, V. (2018), "Empirical Research on Identifying Main Drivers Leading to Integrated Reporting Framework Implementation. The case of European Region”, Romanian Economic Journal, Vol.21 No.70 pp. 52-73.

Cattell, R. B. (1966), “The scree test for the number of factors”, Multivariate Behavioral Research, Vol 1No.2 pp. 245-276.

Cheng, M., Green, W., Conradie, P., Konishi, N. and Romi, A. (2014), “The International Integrated Reporting Framework: Key Issues and Future Research Opportunities”, Journal of International Financial Management and Accounting, Vol. 25 No. 1 pp. 90-119.

Churet, C. and Eccles, R. G. (2014), “ IntegratedReporting, Quality of Management, and Financial Performance.”, Journal of Applied Corporate Finance, Vol.26 No.1 pp. 56-64.

Cohen, S. and Karatzimas, S. (2015), "Tracing the future of reporting in the public sector: introducing integrated popular reporting", International Journal of Public Sector Management, Vol.28 No.6 pp. 449-460.

Conway, E. (2019), “Quantitative impacts of mandatory integrated reporting”, Journal of Financial Reporting and Accounting, Vol.17 No.4 pp. 604-634.

Cortesi, A. and Vena, L. (2019), “Disclosure quality under Integrated Reporting: A value 
relevance approach”, Journal of Cleaner Production, Vol.220 No.1 pp. 745-755.

Crossan, M. M. and Apaydin, M. (2010) 'A multi-dimensional framework of organizational innovation: A systematic review of the literature', Journal of Management Studies, Vol-47 No.6 pp. $1154-1191$.

Druckman, P., and Fries, J. (2010) 'The Future of Corporate Reporting? In: Eccles, R.G., Cheng, B. and Saltzman, D. eds. The Landscape of Integrated Reporting Reflections and Next Steps.', Cambridge, M.A., Harvard Business School, pp.81-85. Available at: https://www2.deloitte.com/content/dam/Deloitte/za/Documents/governance-riskcompliance/ZA_TheRelationshipBetweenCRISAAndRegulation28OfPensionFundsAct04042 014.pdf (Accessed: 10 October 2020).

Dumay, J., Bernardi, C., Guthrie, J. and Demartini, P. (2016), “Integrated reporting: A structured literature review", Accounting Forum, Vol. 40 No. 3 pp. 166-185.

Dumay, J. (2016) 'A critical reflection on the future of intellectual capital: from reporting to disclosure', Journal of Intellectual Capital, Vol.17 No.1 pp. 168-184.

Dumay, J., Bernardi, C., Guthrie, J. and La Torre, M. (2017), "Barriers to implementing the International Integrated Reporting Framework: A contemporary academic perspective", Meditari Accountancy Research, Vol. 25 No. 4 pp. 461-480.

Dumay, J. and Dai, T. (2017) 'Integrated thinking as a cultural control?', Meditari Accountancy Research. Vol.26 No.3 pp. 574-604.

Dumay, J., Guthrie, J. and Farneti, F. (2010) 'GRI sustainability reporting guidelines for public and third sector organizations: A critical review', Public Management Review, Vol. 12 No.4 pp. 531-548.

Eccles R.G., Krzus M.P. (2010), One Report: Integrated Reporting for a Sustainable Strategy, Wiley, Newyork USA.

Eccles, R. G. and Serafeim, G. (2017), “Corporate and integrated reporting: A functional perspective", in Corporate Stewardship: Achieving Sustainable Effectiveness.

Eccles, Robert G. and Krzus, Michael P. and Solano, Carlos (2019), “A Comparative Analysis of Integrated Reporting in Ten Countries" SSRN Electronic Journal Elgammal, M. M., Hussainey, K. and Ahmed, F. (2018), “Corporate governance and 
voluntary risk and forward-looking disclosures", Journal of Applied Accounting Research, Vol.19 No.4 pp. 592-607.

Elkington, J. (1997), "Cannibals with forks: the triple bottom line of 21st Century Business, Capstone, Oxford.”, Capestone, London.

Elkington, J. (1998), "Partnerships from cannibals with forks: The triple bottom line of 21stcentury business", Environmental Quality Management, Vol.8 No.1 pp. 37-51.

Federica, D., Andrea, G. and Pasquale, P. (2016), "Early adopters of integrated reporting: The case of the mining industry in South Africa", African Journal of Business Management, Vol.10 No.9 pp. 187-208.

Field, A. (2013), “Discovering statistics using IBM SPSS statistics, Statistics” Sage Publication, USA.

Flower, J. (2014), “Critical Perspectives on Accounting The International Integrated Reporting Council : A story of failure”, Critical Perspectives on Accounting, Vol.15 No.1 pp. $1-17$.

Frias-Aceituno, J. V., Rodríguez-Ariza, L. and Garcia-Sánchez, I. M. (2014), “Explanatory Factors of Integrated Sustainability and Financial Reporting”, Business Strategy and the Environment, Vol.23 No.1 pp. 56-72.

Gasperini, F. D. (2014), “The Internal Integrated Reporting and The Value Creation : a Case Study Approach", in IKFAD, p.p 2658-2696.

Ghani, Erlane K., Jamal, Jauharoh, Puspitasari, Evita and Gunardi, Ardi, (2018), "Factors influencing integrated reporting practices among Malaysian public listed real property companies: a sustainable development effort”, International Journal of Managerial and Financial Accounting, Vol.10, No. 2 pp. 144-162.

Ghosh.S (2019), “Integrated Reporting in India: Research Findings and Insights”, Integrated Reporting Antecedents and Perspectives for Organizations and Stakeholders, Springer, pp $365-386$

Gie Yong, A. and Pearce, S. (2013), “ $A$ Beginner's Guide to Factor Analysis: Focusing on Exploratory Factor Analysis", Tutorials in Quantitative Methods for Psychology, Vol. 9 No.2 pp. 79-94. 
Goforth, C. (2015) Using and interpreting Cronbach's Alpha, University of Virginia Library.

Gray, R. (2002) 'The social accounting project and Accounting Organizations and Society.

Privileging engagement, imaginings, new accountings and pragmatism over critique?', Accounting, Organizations and Society, Vol.27 No.7 pp. 687-708.

Haller, A. and van Staden, C. (2014) 'The value added statement - an appropriate instrument for integrated reporting', Accounting, Auditing and Accountability Journal, Vol.27 No.7 pp. 1190-1216.

Havlová, K. (2015) 'What Integrated Reporting Changed: The Case Study of Early Adopters', Procedia Economics and Finance, Vol. 34 pp. 231-237.

Holgado-Tello, F.P., Chacón-Moscoso, S., Barbero-García. (2010), "Polychoric versus Pearson correlations in exploratory and confirmatory factor analysis of ordinal variables", Quality and Quantity, Vol.44 No.1 pp. 153-166.

Humphrey, C., O’Dwyer, B. and Unerman, J. (2017) 'Re-theorizing the configuration of organizational fields: the IIRC and the pursuit of "Enlightened" corporate reporting', Accounting and Business Research, Vol.47 No.1 pp. 30-63.

IIRC. (2011), "Towards Integrated Reporting. Communicating Value in the 21st Century”, available at: http://integratedreporting.org/wp-content/uploads/2011/09/IRDiscussion-Paper2011_spreads.pdf (accessed 31 January 2019).

IIRC. (2013), “The International Framework”, available at: https:// integratedreporting.org/ wp-content/uploads/2013/12/13-12-08-THEINTERNATIONAL-IR-FRAMEWORK-2-1.pdf (accessed 31 January 2019).

IIRC. (2015), “The Integrated Reporting journey: the inside story”, available at: http://integratedreporting.org/wp-content/uploads/2015/ 07/The-IntegratedReporting-journeythe-inside-story.pdf (accessed 15 November 2019).

IIRC report, Building Momentum (2018) https://integratedreporting.org/wpcontent/uploads/2020/05/IIRC_INTEGRATED_REPORT_2018.pdf, (accessed 30 January 2019).

Jensen, J. C. and Berg, N. (2012) 'Determinants of Traditional Sustainability Reporting Versus Integrated Reporting. An Institutionalist Approach', Business Strategy and the Environment, Vol.21 No.5 pp. 299-316. 
Prem Lal Joshi, Abdullah Sallehhuddin \& Predeeban Munusamy \& Ashutosh Deshmukh, (2019), "Benefits and Adoption of Integrated Reporting: Perceptions of the Malaysian Corporate Accountants," International Journal of Knowledge-Based Organizations (IJKBO), IGI Global, Vol. 9 No.4 pp 50-64.

Kinser, J. M. and Kinser, J. M. (2018) 'Principle Component Analysis', in Image Operators, Springer, USA.

Kılıç, M. and Kuzey, C. (2018) 'Determinants of forward-looking disclosures in integrated reporting', Managerial Auditing Journal,Vol. 33 No.1 pp. 115-144.

Krzus, M. P. (2011) 'Integrated reporting: if not now, when?', Blickpunkt: Integrated Reporting.

Kurniawan, P. S. and Wahyuni, M. A. (2018), “Integrated Reporting : An empirical evidence from Indonesian”, Jurnal Akuntansi dan Pendidikan, Vol. 7 No.2 pp. 141-155.

Lipunga, A. M. (2015), "Integrated Reporting in Developing Countries: Evidence from Malawi”, Journal of Management Research, Vol.7 No.3 pp 130.

Lodhia, S. (2015), “Exploring the Transition to Integrated Reporting Through a Practice Lens: An Australian Customer Owned Bank Perspective", Journal of Business Ethics, Vol.129 No.3 pp. 585-598.

Melloni, G., Caglio, A. and Perego, P. (2017), "Saying more with less? Disclosure conciseness, completeness and balance in Integrated Reports", Journal of Accounting and Public Policy, Vol-36 No.3 pp. 220-238.

Morros, J. (2016), "Intangible Capital The integrated reporting: A presentation of the current state of art and aspects of integrated reporting that need further development", Intellectual Capital, Vol.12 No-1 pp. 336-356.

Mertins, K., Kohl, H. and Orth, R. (2012), "Integrated Reporting and Integrated Thinking - A Resource oriented Perspective", EIASM - 8th Interdisciplinary Workshop on Intangibles, Intellectual Capital \& Extra-Financial Information.

Mishra.N (2020), International view: Integrated Reporting - A Trouble-shooter for Indian Reporting | Integrated Reporting SA, Integrated Reporting Committee of South Africa. Available at: https://integratedreportingsa.org/international-view-integrated-reporting-atrouble-shooter-for-indian-reporting/ (Accessed: 26 November 2020). 
Mishra, N. (2020a), India desperately needs one more reform - integrated reporting | Integrated Reporting, IIRC. Available at: https://integratedreporting.org/news/indiadesperately-needs-one-more-reform-integrated-reporting/ (Accessed: 26 November 2020).

Mishra, N. (2020b), 'Integrated Reporting: A Structured Analysis of Application and Gaps in India', Texila Internation Journal of Management, Vol.11No.3 pp. 24-30.

Mishra, N. (2020c) Understanding Value Creation | IFAC, IFAC. Available at: https://www.ifac.org/knowledge-gateway/preparing-future-readyprofessionals/publications/understanding-value-creation (Accessed: 22 September 2020).

Nurkumalasari, I. S., Restuningdiah, N. and Sidharta, E. A. (2019), "Integrated reporting disclosure and its impact on firm value: Evidence in Asia", International Journal of Business, Economics and Law, Vol-7 No.1 pp. 173-184.

Pavlopoulos, A., Magnis, C. and Iatridis, G. E. (2019), "Integrated reporting: An accounting disclosure tool for high quality financial reporting", Research in International Business and Finance, Vol.49 pp. 13-40.

Reimsbach, D., Hahn, R. and Gürtürk, A. (2018), "Integrated Reporting and Assurance of Sustainability Information: An Experimental Study on Professional Investors' Information Processing”, European Accounting Review, Vol-27 No.3, pp. 559-581.

Reuter, M. and Messner, M. (2015) 'Lobbying on the integrated reporting framework', Accounting, Auditing \& Accountability Journal, Vol. 28 No. 3 pp. 365-402.

Robertson, F. A. and Samy, M. (2015), "Factors affecting the diffusion of integrated reporting - a UK FTSE 100 perspective”, Sustainability Accounting, Management and Policy Journal, Vol.6 No.2 pp. 190-223.

Rowbottom, N. and Locke, J. (2016), "The emergence of $<\mathrm{IR}>$ ", Accounting and Business Research,Vol. 46 No.1 pp. 83-115.

SEBI (2017), “Integrated Reporting by Listed Entities”, 4(1), pp. 1-8. Available at: https://www.sebi.gov.in/sebi_data/attachdocs/1486375066836.pdf.

Sierra-García, L., Zorio-Grima, A. and García-Benau, M. A. (2015), “Stakeholder Engagement, Corporate Social Responsibility and Integrated Reporting: An Exploratory Study", Corporate Social Responsibility and Environmental Management, Vol.22 No.5 pp. 286-304. 
Soyka, P. A. (2013), “The International Integrated Reporting Council (IIRC) Integrated Reporting Framework: Toward Better Sustainability Reporting and (Way) Beyond", Environmental Quality Management, Vol.23 No.2 pp. 1-14.

Stacchezzini, R., Melloni, G. and Lai, A. (2016), "Sustainability management and reporting: the role of integrated reporting for communicating corporate sustainability management", Journal of Cleaner Production, Vol.136 pp. 102-110.

Stubbs, W. and Higgins, C. (2014), "Integrated reporting and internal mechanisms of change", Accounting, Auditing and Accountability Journal, Vol.27 No.7 pp. 1068-1089.

du Toit, E., van Zyl, R. and Schütte, G. (2017), "Integrated reporting by South African companies: a case study", Meditari Accountancy Research, Vol. 25 No. 4 pp. 654-674.

La Torre, M, Dumay, J, Rea, MA \& Abhayawansa, S (2020), “A journey towards a safe harbour: The rhetorical process of the International Integrated Reporting Council”, British Accounting Review, Vol. 52, no. 2, 100836 pp. 1-22.

Varenova, D., Samy, M. and Combs, A. (2013), "Corporate social responsibility and profitability: trade-off or synergy", Sustainability Accounting, Management and Policy Journal, Vol. 4 No. 2 pp. 190-215.

de Villiers, C., Rinaldi, L. and Unerman, J. (2014), "Integrated reporting: Insights, gaps and an agenda for future research", Accounting, Auditing and Accountability Journal, Vol. 27 No. 7 pp. $1042-1067$.

de Vries, K. (2020) 'Case study methodology', in Critical Qualitative Health Research: Exploring Philosophies, Politics and Practices. Taylor and Francis.

Watkins, M. W. (2006), “Determining parallel analysis criteria”, Journal of Modern Applied Statistical Methods, Vol.5 No.2 pp. 344-346. 
Figures \& Tables

Figure 1 - Correlation matrix

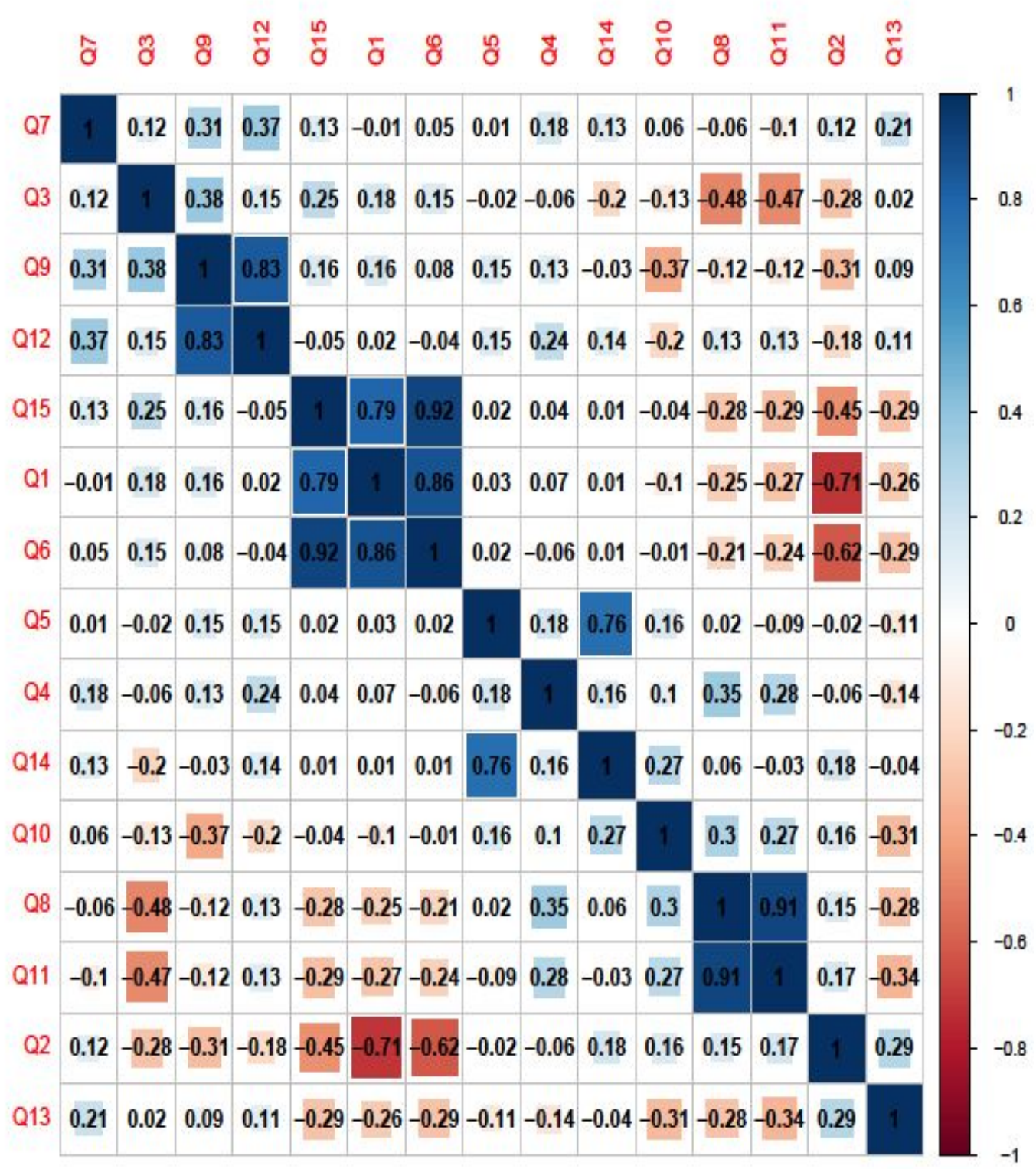

Source-Author's Calculation 


\section{Figure-2 Scree plot}

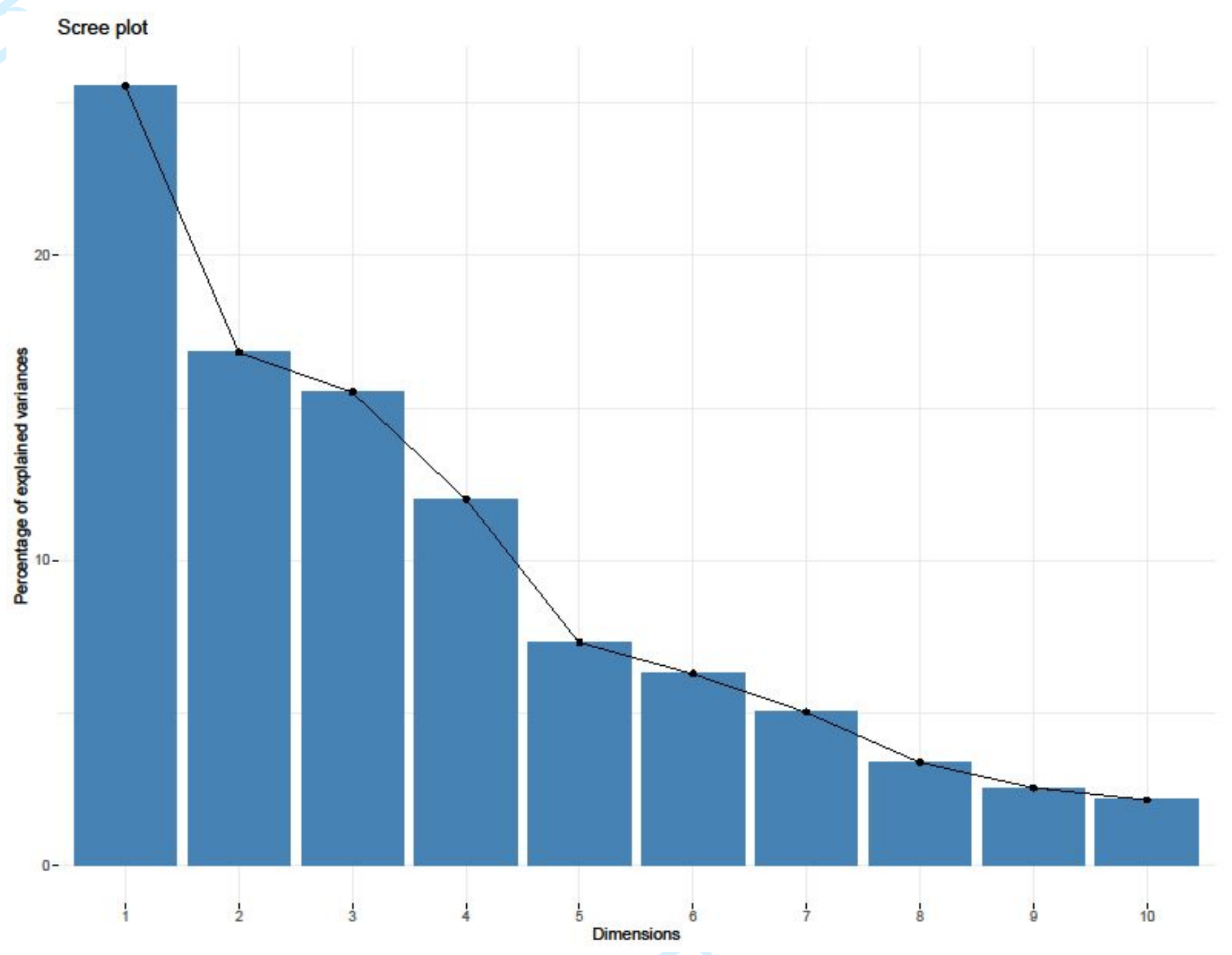


Table 1: Demographic Analysis

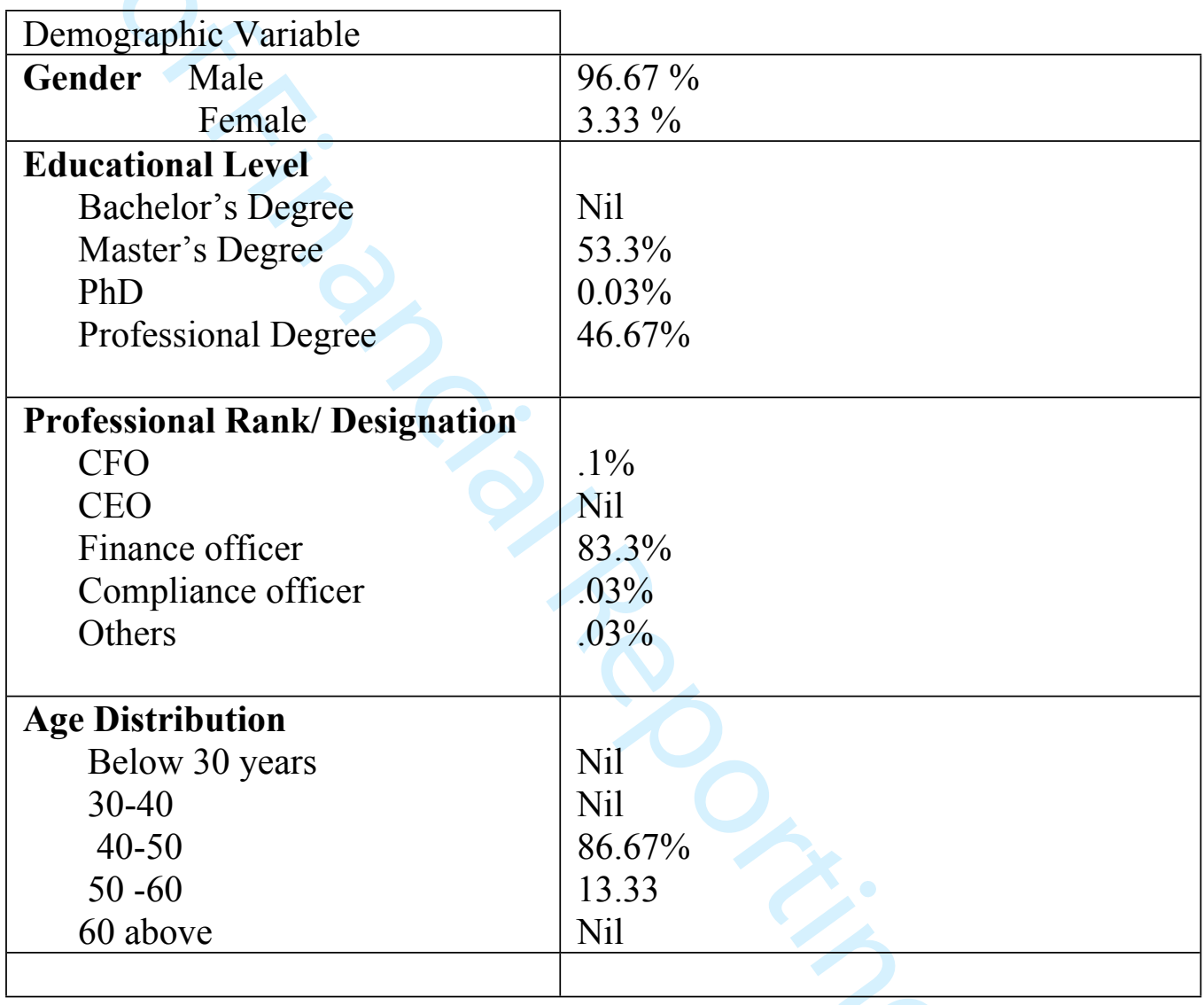

Source-Author's Calculation

Table 2: Sample size and Number of Responses

\begin{tabular}{|l|l|l|l|}
\hline Professionals/Designation & Sent & Responses & Response Rate \\
\hline CEO/ CFO & 33 & 3 & $10 \%$ \\
\hline Finance Officer & 33 & 25 & $75.75 \%$ \\
\hline Compliance officer & 33 & 6 & $18.18 \%$ \\
\hline Others & 33 & 9 & $27.27 \%$ \\
\hline Total & 132 & 43 & $32.57 \%$ \\
\hline
\end{tabular}

Source-Author's Calculation 
Table 3: Reliability Statistics (Cronbach's Alpha Test)

\begin{tabular}{|l|l|l|}
\hline Questions & Number of Questions & Cronbach's Alpha \\
\hline Section-B Advantages & 4 & .78 \\
\hline Section-C Implications & 3 & .83 \\
\hline $\begin{array}{l}\text { Section-DFuture } \\
\text { Opportunity }\end{array}$ & 4 & .78 \\
\hline Section-E Challenges & 4 & .67 \\
\hline
\end{tabular}

Source-Author's Calculation

\section{Table 4: Factor Loading}

\begin{tabular}{|c|c|c|c|}
\hline Loadings: & & 9 & \\
\hline & Factor1 & Factor2 & Factor3 \\
\hline Q1 & 0.863 & 28 & \\
\hline Q2 & -0.619 & -0.251 & \\
\hline Q3 & 0.142 & -0.479 & 0.313 \\
\hline Q4 & & 0.335 & 0.175 \\
\hline Q5 & 0.467 & 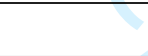 & 0.146 \\
\hline Q6 & 0.997 & s. & 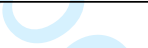 \\
\hline Q7 & & & 0.3 \\
\hline Q8 & -0.179 & 0.946 & 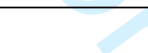 \\
\hline Q9 & & -0.11 & 0.987 \\
\hline Q10 & & 0.311 & -0.139 \\
\hline Q11 & -0.203 & 0.925 & \\
\hline Q12 & & 0.131 & 0.858 \\
\hline Q13 & & & \\
\hline Q14 & & -0.304 & -0.381 \\
\hline Q15 & 0.916 & -0.118 & \\
\hline & Factor1 & Factor2 & Factor3 \\
\hline SS Loadings & 3.161 & 2.398 & 2.144 \\
\hline Proportion var & 0.255 & 0.168 & 0.155 \\
\hline Cumulative var & 0.255 & 0.423 & 0.579 \\
\hline
\end{tabular}

Test of the hypothesis that 3 factors are sufficient. The chi square statistic is 120.59 on 63 degrees of freedom. The $p$-value is $1.73 e-05$

Source-Author's Calculation 
Table 5: Summary of the Factor Categorization

\begin{tabular}{|c|c|c|c|c|c|}
\hline S.No & Factor & Questions & $\begin{array}{l}\text { Eigen } \\
\text { value }\end{array}$ & $\begin{array}{l}\text { \%age of } \\
\text { Variance } \\
\text { explained }\end{array}$ & $\begin{array}{l}\text { Cumulative } \\
\text { variance }\end{array}$ \\
\hline Factor-1 & Concise & $\begin{array}{l}\text { Q1. Do you feel that the } \\
\text { integrated reporting is } \\
\text { concise reporting? } \\
\text { Q2. Do you feel that } \\
\text { integrated reporting is } \\
\text { efficient from the time } \\
\text { prospect? } \\
\text { Q5. Will implementation of } \\
\text { integrated reporting help in } \\
\text { ESG reporting in future? } \\
\text { Q6 Do you feel that } \\
\text { integrated reporting will help } \\
\text { companies in making better } \\
\text { business models } \\
\text { Q15.Do you feel that } \\
\text { adoption of integrated } \\
\text { reporting will lead to } \\
\text { inconsistency among the } \\
\text { annual reports. }\end{array}$ & 3.83 & $25.56 \%$ & $25.56 \%$ \\
\hline $\begin{array}{l}\text { Factor }-2 \\
\backslash\end{array}$ & $\begin{array}{l}\text { Transparent } \\
\text { and } \\
\text { effective }\end{array}$ & $\begin{array}{l}\text { Q4. Do you think that } \\
\text { integrated reporting enhances } \\
\text { transparence in reporting? } \\
\text { Q8. Do you think integrated } \\
\text { reporting will help in } \\
\text { effective communication in } \\
\text { future? } \\
\text { Q10. Will the integrated } \\
\text { reporting will help in } \\
\text { attracting customers in } \\
\text { future? } \\
\text { Q14. Has integrated reporting } \\
\text { generated trust among the } \\
\text { various stakeholders }\end{array}$ & 2.52 & $16.81 \%$ & $42.38 \%$ \\
\hline
\end{tabular}




\begin{tabular}{|c|c|c|c|c|c|}
\hline Factor- 3 & $\begin{array}{l}\text { Better } \\
\text { decision }\end{array}$ & $\begin{array}{l}\text { Q3. Do you think companies } \\
\text { following integrated } \\
\text { reporting will be able to get } \\
\text { better financing? } \\
\text { Q4. Do you think by } \\
\text { following various principles } \\
\text { of integrated reporting } \\
\text { companies will be able to } \\
\text { make better decision making } \\
\text { in future? } \\
\text { Q9. Do you think companies } \\
\text { following integrated } \\
\text { reporting will be able to } \\
\text { generate better value creation } \\
\text { model in future? } \\
\text { Q11. Do you think that } \\
\text { companies following } \\
\text { integrated reporting will be } \\
\text { able to attract more } \\
\text { investors? } \\
\text { Q12. Do you think because } \\
\text { of principle based } \\
\text { framework, integrated } \\
\text { reporting is exposed to } \\
\text { misinterpretation? }\end{array}$ & 2.32 & $15.52 \%$ & $57.90 \%$ \\
\hline
\end{tabular}

Table 6: Finance Personnel have clear Understanding of $<I R>$

\begin{tabular}{|l|l|l|}
\hline & Percent & Cumulative percent \\
\hline Yes & 28 & 28 \\
\hline No & 72 & 100 \\
\hline
\end{tabular}

Source-Author's Calculation

Table 7: Audit assurance of $<I R>$ is complex

\begin{tabular}{|l|l|l|}
\hline & Percent & Cumulative percent \\
\hline Yes & 81.5 & 81.5 \\
\hline No & 18.5 & 100 \\
\hline
\end{tabular}

Source-Author's Calculation 
Table 8 - Summary of Case Study Analysis

\begin{tabular}{|c|c|c|c|c|}
\hline Parameters & Tata Steel & JSW Steel & Vedanta Ltd & L\&T \\
\hline Type of IR & $\begin{array}{l}\text { Full IR Annual } \\
\text { Report } \\
\text { Digital }\end{array}$ & $\begin{array}{ll}\text { Full } & \text { IR } \\
\text { Annual } & \\
\text { Report } & \\
\end{array}$ & $\begin{array}{l}\text { Full IR Annual } \\
\text { Report }\end{array}$ & $\begin{array}{l}\text { Standalone } \\
\text { Annual } \\
\text { Report. }\end{array}$ \\
\hline $\begin{array}{ll}\text { Year } & \text { of } \\
\text { Adoption } & \text { of } \\
\text { IR } & \\
\end{array}$ & $2015-16$ & $2017-18$ & $2017-18$ & $2017-18$ \\
\hline $\begin{array}{l}\text { Defining } \\
\text { Capital( } \\
\text { Unique } \\
\text { Feature) }\end{array}$ & $\begin{array}{l}\text { Impact on } \\
\text { SDGs }\end{array}$ & $\begin{array}{l}\text { Early } \\
\text { disclosure } \\
\text { with separate } \\
\text { unit for } \\
\text { outcome \& } \\
\text { output } \\
\text { interlinkage }\end{array}$ & $\begin{array}{l}\text { Comparatively } \\
\text { less disclosures }\end{array}$ & $\begin{array}{l}\text { Unique } \\
\text { "Business } \\
\text { Model" } \\
\text { Construction }\end{array}$ \\
\hline $\begin{array}{l}\text { Value } \\
\text { Creation } \\
\text { model } \\
\end{array}$ & $\begin{array}{l}\text { Clear model } \\
\text { presented }\end{array}$ & $\begin{array}{lr}\text { Model } & \text { linked } \\
\text { with } & \text { six } \\
\text { capitals } & \\
\end{array}$ & $\begin{array}{lr}\text { Model } & \text { linked } \\
\text { with } & \text { six } \\
\text { capitals } & \\
\end{array}$ & $\begin{array}{l}\text { Lacks } \\
\text { emphasis }\end{array}$ \\
\hline $\begin{array}{l}\text { Stakeholder } \\
\text { engagement } \\
\text { and } \\
\text { materiality }\end{array}$ & $\begin{array}{l}\text { Clearly shows } \\
\text { Environmental, } \\
\text { Social and } \\
\text { Governance } \\
\text { (ESG) material } \\
\text { issues and } \\
\text { incorporated } \\
\text { them in its } \\
\text { long-term plans }\end{array}$ & $\begin{array}{l}\text { No separate } \\
\text { disclosure }\end{array}$ & $\begin{array}{l}\text { Connects it } \\
\text { with } \\
\text { sustainability } \\
\text { targets and } \\
\text { performance on } \\
\text { these material } \\
\text { issues as part of } \\
\text { its strategic } \\
\text { framework }\end{array}$ & No matrix \\
\hline $\begin{array}{l}\text { Risk \& } \\
\text { Opportunity }\end{array}$ & $\begin{array}{lr}9 & \text { Risk } \\
\text { identified } & \& \\
\text { emphasized } & \end{array}$ & $\begin{array}{l}\text { Moderate } \\
\text { disclosure } \\
\text { about risk and } \\
\text { opportunity }\end{array}$ & $\begin{array}{lr}4 & \text { Risk } \\
\text { identified and } \\
\text { related with } \\
\text { initiative and } \\
\text { opportunities }\end{array}$ & $\begin{array}{l}\text { Moderate } \\
\text { disclosure } \\
\text { about risk and } \\
\text { opportunity }\end{array}$ \\
\hline $\begin{array}{l}\text { Environment } \\
\text { and Social } \\
\text { disclosure }\end{array}$ & $\begin{array}{l}\text { Separate } \\
\text { heading“ } \\
\& \text { Social } \\
\text { Capital" Relating } \\
\end{array}$ & $\begin{array}{l}\text { Part of } \\
\text { mandatory } \\
\text { disclosures }\end{array}$ & $\begin{array}{l}\text { Separate } \\
\text { heading" } \\
\text { Sustainability } \\
\text { \&CSR" }\end{array}$ & $\begin{array}{l}\text { Part of } \\
\text { mandatory } \\
\text { disclosures }\end{array}$ \\
\hline $\begin{array}{l}\text { Performance } \\
\text { analysis and } \\
\text { SDGs }\end{array}$ & $\begin{array}{l}\text { Connected } \\
\text { SDGs with Six } \\
\text { Capital }\end{array}$ & $\begin{array}{l}\text { Dedicated } \\
\text { page for } \\
\text { SDGs }\end{array}$ & Less emphasis & Less emphasis \\
\hline
\end{tabular}

Source-Author's Interpretation 